\title{
Inclusion of children with autism spectrum disorders through shared peer activity
}

\author{
Stephen Von Tetzchner* \\ Elisabeth Grindheim**
}

\begin{abstract}
Inclusion may be defined as having a full and active part in the life of the mainstream kindergarten or school. There are professional, political and ethical reasons for striving for inclusion and there are different approaches to how inclusive education and training of children with autism spectrum disorders (ASD) should be organized. The basis for the illustrative case excerpts presented here is a blend of social constructivism, event cognition and ecological psychology. Children with ASD vary widely and intervention has to be based on knowledge about development, learning and autism in general, as well as knowledge about the individual child and his or her proximal environment or ecology. Many children with ASD need some one-to-one education but participation in child-managed activities and events is a core element of true inclusion. The case excerpts illustrate principles for how this may be achieved.
\end{abstract}

Keywords: Autism Spectrum Disorder; inclusion; peer relations; enculturation.

* Professor at The National Autism Unit, Oslo University Hospital, Oslo, Norway.

** Professor at The National Autism Unit, Oslo University Hospital, Oslo, Norway. 


\title{
A inclusão de crianças com Transtornos do Espectro do Autismo através de atividade compartilhada com seus pares
}

\begin{abstract}
Resumo
Inclusão pode ser definida como desempenhar um papel pleno e ativo no contexto regular da escola ou da pré-escola. Há razões profissionais, política e ética para lutar pela inclusão e existem diferentes abordagens que versam sobre como a educação inclusiva e o treinamento de crianças com transtornos do espectro do autismo (TEA) devam ser organizados. Os casos ilustrados no presente trabalho fundamentam-se em uma combinação de abordagens incluindo o construtivismo social, a cognição de eventos e a psicologia ecológica. As características de crianças com TEA variam amplamente e a intervenção deve ter como base o conhecimento sobre desenvolvimento, aprendizagem e o autismo em geral, assim como informações sobre a criança e seu ambiente proximal ou ecológico. Muitas crianças com TEA precisam de educação individualizada, mas a participação em atividades e eventos dirigidos pela criança é um elemento essencial da verdadeira inclusão. Os casos ilustram os princípios de como isso pode ser alcançado.
\end{abstract}

Palavras-chave: Autismo; Inclusão; Relação de pares; Inculturação.

\section{Introduction}

In developmental and educational research, recurring questions have been where children with disabilities should get their education and training and how such services should be organized in society (e.g., GIBB; TUNBRIDGE; CHOA; FREDERICKSON, 2007; GÖRANSSON, 2007; KEIL; MILLER; COBB, 2007; ZIGMOND, 2003). These questions may be seen from different but related perspectives: professional, ethical and political. The professional issue is how one can best support learning and development in children with atypical or deviant development. The ethical perspective is that children with disabilities are equal members of society and should have the same opportunities as others to realize their potential for development and participation. The political perspective concerns the willingness of society to invest in the education and life quality of children who need more support and resources than other children to become productive citizens or who may not become productive in a traditional sense (cf., COLE, 2005; JACKSON; RYNDAK; WEHMEYER, 2009; LINDSAY, 2007; VON TETZCHNER et al., 2005).

The term "inclusion" may be defined as having a full and active part in the life of the mainstream kindergarten or school, and adaptation of the physical and social environment and the curriculum may be necessary to promote shared learning experiences and social interaction between children with and without disabilities. Degree of inclusion may vary considerable also in non-segregated settings (ELDAR; TALMOR; WOLF-ZUCKERMAN, 2010; JACKSON et al., 2009). In Norway, there are few special schools and full or partial inclusion is therefore the rule. This 
is primarily a results of political decisions but also a consequence of the fact that Norway has a small population in relation to the geographical size. It is therefore important to develop educational approaches that may utilize the possibilities of inclusive settings.

Children with autism spectrum disorders (ASD) vary widely (SILLER; SIGMAN, 2008; VAN ENGELEAND; BUITELAAR, 2008). Some show near age appropriate cognition and language development but with some pragmatic and social problems. Others are severely intellectually impaired and may develop little or no spoken language (ANDERSON et al., 2007; KELLEY et al., 2006; KJELGAARD; TAGER-FLUSBERG, 2001; VOLDEN et al., 2009). Some have an extraordinary form of language development with alternative means of communication but the final goal is inclusion, that they shall be able to communicate with peers and adults about the same things and in the same situations as naturally speaking children (VON TETZCHNER, 2009; VON TETZCHNER; MARTINSEN, 2002).

There are many hindrances to true or full inclusion. Teachers may have little or no experience with ASD and feel that they lack the necessary qualifications and need help and support to be able to promote learning and development in a child with ASD (MARSHALL; RALPH; PALMER, 2002; RAVET, 2012). Many teachers do not want to have children with ASD in their classroom and believe it is better for them to be educated in special educational settings with one-to-one training (ENGSTRAND; ROLL-PETTERSON, 2012; SYMES; HUMPHREY, 2010), but segregated education is not supported by research and the need for intensive one-toone instruction is claimed to be a myth (PRIZANT, 2009; STRAIN; SCHWARTZ; BARTON, 2011). Moreover, reduced social communication and interaction are defining characteristics of autism spectrum disorder in DSM-V (LORD; JONES, 2012; OZONOFF, 2012) and there is no evidence that children with ASD will show better social development or academic learning in segregated than in non-segregated settings (HOWLIN et al., 2009; MAGIATI et al., 201l; WARREN et al., 2011). However, children with ASD in ordinary educational settings may not pay attention to the other children or may be spectators only to many of the things they are doing. Without support they may have few truly shared activities and few opportunities for interactions with other children. Such circumstances are not truly inclusive and may not fulfill their expected educational aims and functions.

Teaching and learning is never decontextualized (JACKSON et al., 2009). A characteristic of true inclusion is that it comprises not only direct educational situations but the whole set of events and activities that are the foundation of meaning making in kindergarten and school, including play and social interaction during breaks and on the way to and from kindergarten and school (MULVIHILL; SHEARER; VAN HORN, 2002; VON TETZCHNER et al., 2005). Inclusion is thus not only about developing academic skills or increasing wanted and reducing unwanted behavior, but about enculturation in a broad sense. Enculturation - learning the ways and means of the culture - is an essential part of children's development (VON TETZCHNER, 2012). As children are guided by more competent children and adults into the culture they come to share a means of communication, meaning and cultural 
knowledge related to a wide range of events involving people in the community (BRONFENBRENNER; MORRIS, 2006; NELSON, 2007; VYGOTSKY, 1962). This blend of social constructivism, event cognition and ecology is also the theoretical bases of the approach to inclusive intervention presented here (see also JACKSON et al., 2009).

Much of children's meaning making is taking place within activities of the peer culture which to some extent evolves independent although as part of children's life in society in general. Many developmental researchers have pointed out that horizontal peer relations afford interactions that are qualitatively different from those of the vertical adult child relations (PIAGET, 1932; DUNN, 1988, 1999; KEMPLE, 2004; HARTRUP, 1989). Studies have found that the interaction with peers may facilitate learning and development in children with ASD and other disabilities (GULDBERG, 2010; VON TETZCHNER et al., 2005). Interaction with peers may contribute to inclusion and the development of social and cultural knowledge and skills in a way that cannot be easily achieved by teacher instruction and adult child interactions. Facilitation of participation in the peer culture is therefore an inherent element of all inclusion as well as an aim of inclusive interventions. Children in inclusive intervention may have some one-to-one training but it is a requirement that this training should be comprehensible and meaningful for the child and lead to strengthened social interactions with peers throughout the day. However, even when utilizing everyday situations, many professionals tend to adopt a training oriented style and create a continuous sequence of training activities that may contribute to segregation rather than inclusion.

Many authors write about comprehensive education for children with ASD without mentioning peers (e.g., Lynch \& Irvine, 2009; Marks, 2007; Strain et al.,, 2011). Other authors mention peers but focus mainly on their potential role as a helper and source of prompts, reinforcement and positive pressure in inclusive educational settings (e.g., CROSLAND \& DUNLAP, 2012, OSTROSKY; KAISER; ODOM, 1993; KOEGEL; MATOS-FREDEN; LANG; KOEGEL, 2012; SPERRY; NEITZEL; ENGELHART-WELLS, 2010). Knowledge about behavioral strategies may be useful in some situations and help peers support skill acquisition in the child with ASD (BREITENBACH; ARMSTRONG; BRYSON, 2013). However, making peers into small teachers will influence how they interact with the child with ASD and may hinder his participation in ordinary child-managed activities.

The aim of the present approach is to adapt child-managed activities to support inclusion of a child with ASD without turning these activities into adultdirected education. This is illustrated in the case excerpts below, which go beyond skill training and provision of rewards and focus on promoting inclusion through independent peer interactions in shared activities. The aim is to guide children in kindergarten and school to function as knowledgeable peers who will be tolerant and willing to take part in activities with the child with ASD as an equal participant (see also CAMPBELL et al., 2004). This may involve situations where a peer helps the child with ASD performing a skill that is needed in that particular situation, but it is participation in shared activities with peers, negotiation and insight into ordinary 
child-managed events - rather than adult-directed skill training - that is the focus of the inclusive education. When attempting to create a truly inclusive environment, the teachers utilize that peers are both more competent than the child with ASD and more equal to this child than the teacher.

\section{Illustrative case excerpts}

The excerpts of case studies presented here illustrate strategies that may promote social inclusion of children with ASD in the peer groups in ordinary kindergarten and schools, and how such inclusion may support learning and development. They build on the assumption that shared activities naturally afford communication and negotiation among children, and that peer negotiation of roles and turns will contribute to shared understanding and context.

All the focus children in the excerpts had a diagnosis of ASD and the overall educational aim was to promote communication, social learning and participation in peer-managed activities that was meaningful for the child with ASD. The normally developing children were told that some children have problems with learning, communication and understanding other people, and that the focus child in their kindergarten or school was one of those who have such problems. The information was adjusted to the children's developmental level, and they were given practical examples so that the behaviour of the child with ASD would be meaningful for them. The term "autism" was not mentioned until the peers were old enough to make sense of this category.

\section{Activities and negotiation}

The first excerpt is about Peter. He was four years old, had no spoken language but good motor skills and liked physical rough and tumble play. Although it was not possible to test him formally, he appeared to have non-verbal cognitive resources. He attended an ordinary kindergarten with some extra staff and resources, and followed a behavior-oriented program part of the time which consisted of individual training indoors with a focus on skill training and structure. Training with manual signs and Picture Communication Symbols (PCS) had recently been initiated but these communication forms had not yet become an integral part of the kindergarten and his behavioral program focused more on structure than on communication. Peter sometimes looked at the other children and occasionally approached them but did not try to become part of whatever they were doing. He was rarely part of the ordinary events and hence missed many opportunities for incidental social learning from peer and adults in the kindergarten, learning which should have been within reach in spite of his autism condition. His outdoor activities were less formalized and structured. He spent much of the outdoor time in solitary activities where the skills that were trained indoors had little or no function.

After a discussion of the intervention, the direction was changed towards true inclusion as this was assumed to promote a greater degree and more varied 
participation. The two major foci was communication and interaction with other children, while maintaining his need for structure and overview. In order to avoid defining the shared activities as intervention for Peter, an activity path with four stations was generally introduced in the kindergarten, consisting of tricycle, swing, slide and doll house. Time was allocated to the stations and all the children were told to follow the path and change from one station to the next in a regular order when the teacher called out «Station shift». At each station, the children had to follow order and wait for their turn, and it was left to the children to sort this out themselves as much as possible. This means that there was a clear and predictable structure that all the children had to follow, but also a need for negotiation that required attention to others, communication and self-regulation. The aim was that this would promote child independence and social interaction between Peter and the peers, even if adult support and guidance sometimes were needed in the beginning. The children were told about Peter's problems with communication and understanding other people and that his tendency to flap the hands meant that he was positively exited and liked the activity he being part of, and that he was not waving goodbye which many of the children actually believed. They were taught the meanings of the items in Peter's PCS vocabulary and how they could use them to communicate with him and lead him in positive activities. They were explained that they could use the manual signs WAIT and STOP to tell him that he did something out of turn or something he should not do. When the activity path was introduced Peter participated with limited adult guidance or interference. In the beginning the groups were carefully selected and there were always some of the socially most skilled children in Peter's group. The teachers corrected out of turn behavior by guiding the younger children, but did not try to correct Peter in this situation. By going along with the others from station to station, he learned the implicit and explicit rules of the activities. The other children would correct him if he tried to do something out of turn and reminded him if he did not take his turn, like they would with everybody else. Because they knew about his problems they tended to be empathetic with him, even when he occasionally misbehaved, and they cheered enthusiastically when he followed the ordinary rules. The children were sometimes annoyed with him, but they wanted to do the station activities and therefore encouraged him to go along. The result was that they gave more attention to his achievements than to his failures to follow the rules.

Six months after the change in the kindergarten program, Peter had become a more playing child. His participation had increased both in quantity and quality. He spent more time together with the other children and had become better in regulating himself socially. In the activity path he had learned where he should go next, paid more attention to the other children's actions, and waited for and took his turn. These are skills which were not easy to promote in the behavior-oriented training. Further, the communication and social skills he learned in the activity path generalized to other situations. Prior to the focus on peer education and shared activities he would usually sit alone with his spade and bucket in the sand box. Now both he and the other children would sometimes take initiative to exchange spade and bucket and other toys. The teachers also reported generalization of his turn taking skills in meals and when he was playing Lotto. They also adapted the PCS training to his actual social participation. They introduced vocabulary items which could be useful in the activities where Peter participated, including the manual signs HELP, 
I (point to self) and YOU (point to another), and the graphic symbols BICYCLE (which is more general than TRICYCLE), SLIDE, SWING, DOLL, HOUSE, BUCKET and SPADE. The communication training with PCS had started rather late but it was when the vocabulary was integrated into the activities that Peter's use of graphic symbols really took off.

\section{Take the sleigh train}

Shared child activity is also the core element in this case excerpt. Roger was five years old. He had mild intellectual disability, used some single-word utterances but progress in his use of spoken language was limited. The kindergarten had therefore recently started to use pictograms. Roger tended to be rigid and inflexible, and reacted strongly to changes in routines. His play was solitary and repetitive, but similar to the other children, he showed enjoyment and good humor when he was engaged in activities he liked. When there was snow outside, he would most of the time go to the top of the hill and sleigh down, again and again. He paid no attention to the activities of the other children and would sleigh down even if somebody was in the tracks.

The kindergarten defined inclusion as the presence of shared activities, independent of the children's strengths and weaknesses. All the children liked sleigh riding, so because Roger did not show interest in other children's activities, it was decided to use sleighing as a starting point and try to expand it into an interactive group activity for the children in the kindergarten. The children had been told how they could try to communicate with him but also that they had to be aware of the fact that because of his autism he did not always understand or pay enough attention to what they were saying or doing.

Group interaction always involves turn-taking and waiting for one's turn. In order to introduce these elements in sleighing, a «sleigh train» was introduced where the children would sit after each other on the sleigh, holding onto the feet of the child behind as they were sleighing down a not too steep hill, together with the rule «No child can sleigh alone». When Roger walked up the hill with his sleigh, the teacher guided him towards another child who was already waiting on his sleigh. This kind of adult guidance was common in many activities in the kindergarten. Roger was helped to sit down behind the other child who held on to Roger's feet and then they sleighed down together. When he went back up, he was again guided to follow the same procedure. He did not react much to the demand that was introduced, but showed enjoyment and continued his repetitive sleighing but now together with others. After a few such turns, there were two children waiting and without much fuss he hooked on as number three on the sleigh and they started downhill the moment he arrived. The next day started like the first but after a few trips, he was number two on the sleigh and had to wait for a third and later a fourth and then fifth child before the sleigh train was set in motion by the lead child.

Riding on this kind of "sleigh train" requires some regulation of self in relation to others. The children sometimes had to sit down and wait for their turn, 
find a slot in the train, and maybe wait for others before the sleigh could be set in motion. They also had to pay attention during the ride and make sure nobody fell off. At the beginning Roger was always the last child on the sleigh and hence had the least waiting, but over time he came closer to the front and fast learned to wait for the others without any severe problems. He even managed to be the first on the sleigh and wait for others. Sometimes the children had different preferences and negotiated their preferred place on the sleigh train. The activity was first maintained by the adult, but the children soon took over and negotiated everything related to sleighing among themselves without any help or interference from adults.

The other children liked to ride on sleigh trains and hence participated for their own pleasure. They did not regard it as intervention for Roger but knew that the kindergarten wanted everybody to be part of it and that they should not turn him away even if he was unruly. It also helped that Roger was known to be an experienced sleigh rider and the other children liked to ride with him as long as he followed the rules that the kindergarten had made for sleigh rides. The peers learned that he was able to do it and began to invite him to sleigh riding without any suggestions from the teachers. One morning a teacher observed Roger standing on the top of the hill with a big smile in his face waving to the others in order to get them on the sleigh. The peers had become more independent and including without adults, and Roger had become included in the peer group.

\section{Go fishing}

This case excerpt illustrates how traditional academic learning may be integrated into child-managed activities. Bob was eight years old and in the beginning of the third grade. He was high functioning but had significant problems learning mathematics. He could remember long sequences of digits, but tasks with addition and subtraction was challenging to him and it was difficult for the teacher to get him to work with such tasks. He did not see why he had to learn mathematics. His special interest was fish, their characteristics and habitats, he was a virtual encyclopedia when it came to fish. It was therefore decided to make fishing trips and visits to the fish shop part of the class' education, blending biology and mathematics. After a fishing trip where they fished in small groups, they would try to find out how many fish each group had caught, how many fish they had all together, how many they gave away and how many they had left. Bob was very motivated and worked seriously with these tasks. The same calculations were made for fish they had bought in the fish store and which he and the children were allowed to take home. Calculations were also extended to details on the fish, which made Bob even more enthusiastic, like how many fins there were in total. Bob found these tasks meaningful and very engaging. He collaborated with the other children to register the number of fish in each catch, usually adding information about the type of fish they had caught, what the fish ate and where it lived, etcetera. 


\section{Perspective drawing}

Harold was in the third grade but tended to sit apart from the other children and had very few shared activities. The teachers had decided that participation in group work was unachievable for him and had not really attempted to make him part of the peer group. Harold liked drawing and was extremely good at it. The teachers would often let him sit alone and draw while the others were doing group work. He did not disturb anybody and the teachers were free to attend to other children in the class. Thus, although Harold's ability to draw was admired by the both teachers and class mates, the autism expert realized that it segregated him from the class. She suggested that to achieve a higher degree of inclusion, participation in group work should be the primary goal of intervention and his drawing skills could be used as an entrance into group work and social interaction in the class. Constitution day was approaching - in Norway, this is May 17th - and the class should work together on a joint presentation to mark this day. The class was divided into groups that worked on different themes to present to the class. One group should draw the building where the constitution had been signed in 1814 , another should write about the history of this event, a third about the official members of the constitution group, and so on. Instead of giving Harold a drawing assignment for himself as they had done before, the teachers placed him in a group with four children that together should make a drawing of the house from old photographs. This drawing should be the center of a poster with text from the other groups. It was a rather difficult task and the children had to look carefully at the different photographs when they planned the drawing. Harold became «the hand» of this work but listened to what others said and was open to drawing suggestions. There were long discussions about color and where the contributions of the different groups should be placed. Both the task and the conversation were meaningful and interesting for Harold. The result - somewhat to the surprise of the teachers - was true collaboration without any need for teacher involvement and Harold's contribution was essential for the good result.

Following this event, Harold was assigned the role as drawer in more group works. Importantly, his role expanded through the collaborations with the peers and he gradually took more part in other aspects of the group work even if some of the topics were less engaging for him. Harold and the other children became more aware of their different perspectives on events in the world but also of the possibility of using each other skills in their school assignments - all of them wanted to succeed in school. They communicated more and Harold became less isolated. When included in the group work in this way, Harold's drawing skills contributed significantly to his inclusion in the class.

\section{Let's go walking}

In this example, shared activities outside school was used to initiate a beginning group identity in the child with ASD and his school mates. Olav was 12 years old. He was considered high functioning but had severe comprehension difficulties. He lived in a small village and was in the sixth grade in an ordinary school. He lacked much tacit social knowledge and seemed unable to identify and 
learn social conventions by himself, and nobody had taught them to him. He was doing all right in academic skills but his lack of understanding of social conventions made him seem strange to his peers and hindered his inclusion and becoming part of the common child culture. He worked mostly alone or with his assistant, and did not have any friends or social interaction with the other children within or outside school. In the breaks he wandered around by himself. He was not happy about this, he expressed both curiosity and feelings of uncertainty and loneliness, and asked his mother many questions about being together with boys, and especially with girls. However, Olav's mother was afraid that too much interaction with other children just would increase the risk for bullying.

The question was how he could become part of the peer culture when he was as he was behaving so strange. The teachers had only focused on academic skills but realized that they would have to integrate explicit introduction of social conventions into Olav's curriculum to expand his social skills and thus reduce his odd behavior if a higher degree of inclusion should be achieved. The school first targeted the convention that one is supposed to say hello to some but not all people when one meets them for the first time each day. When the speech therapist told Olav about this he expressed surprise, he had never paid attention to the greetings other people made. When he started to say hello and look at people's faces, both the peers and the adults found him less strange and more social and friendly, and this was enough to open up for more social participation. The boys in Olav's class spent much of their free time playing football but Olav was neither interested nor skilled in sports. He liked walks in the forest and tenting, and there was Christian youth association near his school that had weekly meeting and arranged walks and tenting in the surrounding forest. The overall frame of the associations' work was organized by the older leaders but the leaders in the meetings were around 20 years old and the meetings thus had a very youthful atmosphere. The young leaders were invited to the class to inform about their activities and Olav liked the activities and felt that he had some skills in this area and therefore began to attend the meetings. Several children in the class shared these interests and also decided to join. Olav's mother felt secure about his participation in the association's arrangements.

Even if he liked this kind of outdoor activities, it was challenging for Olav to go on trips into «the unknown». His participation required considerable preparation by his family, the school and the association's leaders. They made a complete plan of what was going to happen, where they would be going, what they would be doing, where and what they would eat, and so on. In addition Olav insisted on having an emergency plan and a drill for what he named "If the catastrophe strikes", which essentially meant having a cellular telephone with him. He went on two trips which he enjoyed very much. There were no problems and he did not use the telephone thanks to the thorough preparation and planning, and he started to attend the ordinary meetings. Some of the other children in the class had also joined the association and Olav and they naturally constituted a little class group. Even if he continued to spend little time with peers outside school and still was considered somewhat odd, the shared interest and participation in the «nature group» made him an included member of the whole class. He took more part in conversations in the classroom and in breaks, and he became less afraid of girls - even if he found them 
unpredictable, especially when they laughed and he could not understand why. His mother was very relieved because Olav told her that he did not consider himself lonely any more.

\section{Discussion}

Several elements in the peer approach based on participation in childmanaged activities may have contributed to the positive results illustrated here. Firstly, it is acknowledged that the inclusion of children with ASD will have to be based on environmental adaptations. All the excerpts show a need to plan for participation, also when the other children were positive and played an independent role. This required competence and knowledge about the child with ASD. All the teachers had been informed about ASD in general and the characteristics of the child in the class, and they received regular supervision from autism specialists. Ensuring competence among kindergarten and school teachers who have a child with ASD in the class is regarded as a necessary element of «best practice» in inclusive education (BREITENBACH et al., 2013). In these cases the education of the teachers was a blend of knowledge about autism, the individual child and his ecology.

Secondly, studies have noted that success in the social domain usually involve good relations with peers (ELDAR et al., 2010). However, a common problem is that peers keep distance and avoid social interaction, often because the child with ASD do not initiate social interaction or respond to initiations from other in a manner that the peers understand. In the excerpts the peers were informed about the problems the child with ASD was having with communication and social comprehension, but also how they could communicate with him and do things together with him. Unlike behavior-oriented programs that tend to make peers into teacher assistants, they were not told to use of praise or reinforcement. When peers become small teachers, this is not part of an ordinary peer activity and may not support participation based on equality which is the defining characteristic of peer interaction. The peers in the kindergartens and schools were told to acknowledge good efforts and achievements and to encourage attempts in the same way as they would do with the other children in the kindergarten or class. The focus on doing things together, not as an intervention, but as a positive activity, is a distinctive feature of the present case excerpts.

Maybe because the children were somewhat strange at the outset, even quite small achievements in play and social interaction seemed to be enough to change the perceptions of the peers (and adults), and thereby to increase social participation and facilitate enculturation. Several articles make claims about inclusion and «best practice» without mentioning peers (LYNCH; IRVINE, 2009). These are likely to miss out a core element in inclusion. Moreover, in segregated settings, the competence of the (disabled) peers may not be sufficient to support learning and development.

Several authors have pointed to the importance of utilizing the child's good skills, even when these skills are not an important part of the ordinary child 
repertoire (KOEGEL et al., 2012; Martinsen et al., 2006). The life in kindergartens and school contains a variety of activities and it is usually possible to find something that can constitute a basis for joint participation if the program is not too rigid with regard to what activities the child should do. It should also be noted that the activities were not selected for teaching. The play or activity that was selected for shared participation was not considered a means for achieving something else but as an aim in itself. Although very different, they were prototypical activities with elements that could be generalized to new situations. The activities were selected in accordance with the interests and capabilities of the child with ASD, but equally on the basis of their cultural value and possibilities to highlight decisive features and generalize them to other situations. In this way, their ecological value and generalization to other culturally valued activities were never in question.

Finally, the aim of the present paper has been to discuss reasons for inclusion and illustrate some possible inclusive practices for children with ASD. It is acknowledged that some children with ASD may benefit from some one-to-one training but this is not an argument for segregation.

\section{References}

ANDERSON, D. K.; LORD, C.; RISI, S.; DILAVORE, P. S.; SHULMAN, C.; THURM, A.;WELCH, K.; PICKLES, A. Patterns of growth in verbal abilities among children with autism spectrum disorder. Journal of Consulting and Clinical Psychology, v.75, p. 594-604, 2007.

BOUCHER, J. (2012), Research review: Structural language in autistic spectrum disorder characteristics and causes. Journal of Child Psychology and Psychiatry, v. 53, p. 219-233, 2012.

BREITENBACH, M. M.; ARMSTRONG, V. L.; BRYSON, S. E. The implementation of best education practices for a student severely affected by autism. International Journal of Inclusive Education, v. 17, p. 277-294, 2013.

BRONFENBRENNER, U.; MORRIS, P. A. The bioecological model of human developmental. In: Damon, W; Lerner, R. M. (org.), Handbook of child psychology: Theoretical models of human development. New York: John Wiley, v. 1, p. 793-828, 2006.

CAMPBELL, J. M.; FERGUSON, J. E.; HERZINGER, C. V.; JACKSON, J. N.; MARINO, C. A. Combined descriptive and explanatory information improves peers' perceptions of autism. Research in Developmental Disabilities, v. 25, p. 321-339, 2004.

COLE, B. A. (2005) Good faith and effort? Perspectives on educational inclusion. Disability and Society, v. 20, p. 331-344, 2005.

CROSLAND, K.; DUNLAP, G. (2012). Effective strategies for the inclusion of children with autism in general education classrooms. Behavior Modification, v. 36, n. 3, p. 251-269, 2012.

DUNN, J. The beginnings of social understanding. Oxford; UK: Basil Blackwell, 1988.

DUNN, J. Siblings, friends and the development of social understanding. In W.A. Collins, W.A.; Laursen, B. (Org.), Relationships as developmental contexts. Mahwah, New Jersey: Lawrence Erlbaum, 1999, p. 263-279. 
ELDAR, E.; TALMOR, R.; WOLF-ZUKERMAN, T. Successes and difficulties in the individual inclusion of children with Autism Spectrum Disorder (ASD) in the eyes of their coordinators. International Journal of Inclusive Education, v. 14, n. 1, p. 97-114, 2010.

ENGSTRAND, R. Z:; ROLL-PETTERSSON, L. Inclusion of preschool children with autism in Sweden: attitudes and perceived efficacy of preschool teachers. Journal of Research in Special Educational Needs, 2010. doi: 10.1111/j.1471-3802.2012.01252.x

GIBB, K.; TUNBRIDGE, D.; CHUA, A.; FREDERICKSON, N. Pathways to inclusion: moving from special school to mainstream. Educational Psychology in Practice, v. 23, n. 2, p. 109-127, 2007.

GÖRANSSON, K. Pedagogical traditions and conditions for inclusive education. Scandinavian Journal of Disability Research, v. 8, n. 1, p. 67-74, 2006.

GULDBERG, K. Educating children on the autism spectrum: preconditions for inclusion and notions of 'best autism practice' in the early years. British Journal of Special Education, v. 37, p. $168-174,2010$.

HARTRUP, W. W. Social relationships and their developmental significance. American Psychologist, v. 44, p. 120-126, 1989.

HOWLIN, P.; MAGIATI, I.; CHARMAN, T.; MACLEAN, W. E. Systematic review of early intensive behavioral interventions for children with autism. American Journal on Intellectual and Developmental Disabilities, v. 114, n. 1, p. 23-41, 2009.

JACKSON, L.; RYNDAK, D. L.; WEHMEYER, M. L. Access to the general curriculum: the mandate and the role of context in research-based practice for students with extensive support needs. Research and Practice for Persons with Severe Disabilities, v. 33, n. 4, p. 199-213, 2009.

KEIL, S.; MILLER, O.; COBB, R. Special educational needs and disability. British Journal of Special Education, v. 33, p. 168-172, 2006.

KELLEY, E.; PAUL, J.; FEIN, D.; NAIGLES, L. Residual language deficits in children with a history of autism. Journal of Autism and Developmental Disorders, v. 36, p. 807-828, 2006.

KEMPLE, K. M. Let's be friends. Peer competence and social inclusion in early childhood programs. New York: Tetzchner College Press, 2004.

KJELGAARD, M.; TAGER-FLUSBERG, H. An investigation of language impairment in autism: Implications for genetic subgroups. Language and Cognitive Processes, v. 16, n. 2-3, p. $287-308,2001$.

KOEGEL, L.; MATOS-FREDEN, R.; LANG, R.; KOEGEL, R. Interventions for children with autism in inclusive school settings. Cognitive and Behavioral Practice, v. 19, p. 401-412, 2012.

LINDSAY, G. Educational psychology and the effectiveness of inclusive education/ mainstreaming. British Journal of Educational Psychology, v. 77, p. 1-24, 2007.

LORD, C.; JONES, R. M. Annual research review: Re-thinking the classification of autism spectrum disorders. Journal of Child Psychology and Psychiatry, v. 53, p. 490-509. 
LYNCH, S. L.; IRVINE, A. N. Inclusive education and best practice for children with autism spectrum disorder: An integrated approach. International Journal of Inclusive Education, v.13, n. 8, p. 845-859, 2009.

MAGIATI, I.; MOSS, J.; CHARMAN, T.; HOWLIN, P. Patterns of change in children with autism spectrum disorders who received community based comprehensive interventions in their preschool years: A seven year follow up study. Research in Autism Spectrum Disorders, v. 5, p. 1016-1027, 2011.

MARKS, S. U. Can special programs for children with autism spectrum disorders be Inclusive? Research and Practice for Persons with Severe Disabilities, v. 32, n. 4, p. 265-268, 2007.

MARSHALL, J; RALPH, S.; PALMER, S. 'I wasn't trained to work with them': mainstream teachers' attitudes to children with speech and language difficulties. International Journal of Inclusive Education, v. 6, n. 3, p. 199-215, 2002.

MARTINSEN, H.; NÆRLAND, T.; STEINDAL, K.; VONTETZCHNER, S. Barn og ungdommer med Asperger-syndrom: Prinsipper for undervisning og tilrettelegging av skoletilbudet (Children and adolescents with Asperger syndrome: Principles for education and adaptation of the curriculum). Oslo: Gyldendal Akademisk, 2006.

MULVIHILL. B. A.; SHEARER, D.; VAN HORN, M. L. Training, experience and child care providers' perceptions of inclusion. Early Childhood Research Quarterly, v. 17, p. 197-215, 2007.

NELSON, K. Young minds in social worlds: Experience, meaning and memory. Cambridge, Massachusetts: Harvard University Press, 2007.

OSTROSKY, M. M.; KAISER, A. P.; ODOM, S. L. Facilitating children's social-communicative interactions through the use of peer-mediated intervention. In: KAISER, A. P.; GRAY, D. B. (Org.), Enhancing children's communication: Research foundations for intervention. London: Paul H. Brookes, p. 159-185, 1993.

OZONOFF, S. Editorial: DSM-5 and autism spectrum disorders - two decades of perspectives from the JCPP. Journal of Child Psychology and Psychiatry, v. 53, p. e4-e6, 2012.

PIAGET, J. The moral judgment of the child. London: Kegan Paul, 1932.

PRIZANT, B. M. Is ABA the only way? Social Thinking, 2009. Retrieved from 〈http://www. socialthinking.com/index.php?option=com_content\&view=article\&id=106:is-aba-the-onlyway-\&catid=69:published-articles\&Itemid=122>.

RAVET, J. Delving deeper into the black box: formative assessment, inclusion and learners on the autism spectrum. International Journal of Inclusive Education, 2012. DOI:10.1080/13603 116.2012 .719552

SILLER, M.; SIGMAN, M. Modeling londitudinal change in the language abilities of children with autism: Parent behaviours and child characteristics as predictors of change. Developmental Psychology, v. 44, p. 1691-1704, 2008.

SPERRY, L.; NEITZEL, J.; ENGELHARDT-WELLS, K. Peer-mediated instruction and intervention strategies for students with autism spectrum disorders. Preventing School Failure: Alternative Education for Children and Youth, v. 54, n. 4, p. 256-264, 2010. 
Strain, P.; Schwartz, I. S.; Barton, E. E. Providing intervention for young children with autism spectrum disorders: What we still need to accomplish. Journal of Early Intervention, v. 33, n. 4, p. 321-332, 2011.

SYMES,W.; HUMPHREY, N. Peer-group indicators of social inclusion among pupils with autistic spectrum disorders (ASD) in mainstream secondary schools: A comparative study. School Psychology International, v. 31: p. 478-494, 2010.

VAN ENGELAND H. \& BUITELAAR J. (2008). Autism spectrum dsorders. In M. RUTTER, M.; BISHOP, D.; PINE, D.; SCOTT, S.; STEVENSON, J.; TAYLOR, E.; THAPAR, A. (Org.), Rutter's child and adolescent psychiatry, 5th Edition. Oxford: Blackwell, p. 759-781, 2008.

VOLDEN, J.; COOLICAN, J.; GARON, N.; WHITE, J.; BRYSON, S. Brief report: Pragmatic language in autism spectrum disorder: Relationships to measures of ability and disability. Journal of Autism and Developmental Disorders, v. 39, n. 2, p. 388-393, 2009.

VON TETZCHNER, S. Suporte ao desenvolvimento da comunicação suplementar e alternativa. In: DELIBERATO, D.; GONÇALVES, M.J.; MACEDO, E.C. (Org.), Comunicação alternativa: teoria, prática, tecnologias e pesquisa. São Paulo: Memnon Edições Científicas, p. 14-27, 2009.

VON TETZCHNER, S. Utviklingspsykologi, 2. Utgave (Developmental psychology, Second edition). Oslo: Gyldendal Akademisk, 2012.

VON TETZCHNER S.; BREKKE, K. M.; SJØTHUN, B.; GRINDHEIM, E. Inclusão de crianças em educação pré-escolar regular utilizando comunicação suplementar e alternativa. Revista Brasileira de Educação Especial, v. 1l, n. 2, p. 151-184, 2005.

VON TETZCHNER, S.; MARTINSEN, H. Introdução à communicação aumentiva e alternativa. Porto: Porto Editoria, 2002.

VYGOTSKY, L. S. Thought and language. Cambridge, MA: The MIT Press, 1962.

WARREN, Z.; MCPHEETERS, M. L.; SATHE, N.; FOSS-FEIG, J. H.; GLASSER, A.; VEENSTRA-VANDERWEELE, J. A systematic review of early intensive intervention for autism spectrum disorders. Pediatrics, v. 127, n. 5, el303-el311, 2011.

ZIGMOND, N. Where should students with disabilities receive special education services? Is one place better than another? Journal of Special Education, v. 37, p. 193-199, 2003.

\section{Correspondência}

Stephen von Tetzchner - Departament of psychology, University of Oslo, P. O. Box 1094 Blindern, NO-0317 Oslo, Norway.

E-mail: s.v.tetzchner@psykologi.uio.no - egrindhe@ous-hf.no

Recebido em 12 de maio de 2013

Aprovado em 27 de junho de 2013

Revista Educação Especial | v. 26 | n. 47 | p. 507-522 | set./dez. 2013

Santa Maria 
